\title{
Radiative and dynamical contributions to past and future Arctic stratospheric temperature trends
}

\author{
P. Bohlinger ${ }^{1, *}$, B.-M. Sinnhuber ${ }^{1}$, R. Ruhnke ${ }^{1}$, and O. Kirner ${ }^{2}$ \\ ${ }^{1}$ Karlsruhe Institute of Technology, Institute for Meteorology and Climate Research, Karlsruhe, Germany \\ ${ }^{2}$ Karlsruhe Institute of Technology, Steinbuch Centre for Computing, Karlsruhe, Germany \\ *now at: University of Bergen, Geophysical Institute, Bergen, Norway
}

Correspondence to: B.-M. Sinnhuber (bjoern-martin.sinnhuber@kit.edu)

Received: 20 December 2012 - Published in Atmos. Chem. Phys. Discuss.: 13 March 2013

Revised: 20 December 2013 - Accepted: 8 January 2014 - Published: 13 February 2014

\begin{abstract}
Arctic stratospheric ozone depletion is closely linked to the occurrence of low stratospheric temperatures. There are indications that cold winters in the Arctic stratosphere have been getting colder, raising the question if and to what extent a cooling of the Arctic stratosphere may continue into the future. We use meteorological reanalyses from the European Centre for Medium Range Weather Forecasts (ECMWF) ERA-Interim and NASA's ModernEra Retrospective-Analysis for Research and Applications (MERRA) for the past $32 \mathrm{yr}$ together with calculations of the chemistry-climate model (CCM) ECHAM/MESSy Atmospheric Chemistry (EMAC) and models from the ChemistryClimate Model Validation (CCMVal) project to infer radiative and dynamical contributions to long-term Arctic stratospheric temperature changes. For the past three decades the reanalyses show a warming trend in winter and cooling trend in spring and summer, which agree well with trends from the Radiosonde Innovation Composite Homogenization $(\mathrm{RICH})$ adjusted radiosonde data set. Changes in winter and spring are caused by a corresponding change of planetary wave activity with increases in winter and decreases in spring. During winter the increase of planetary wave activity is counteracted by a residual radiatively induced cooling. Stratospheric radiatively induced cooling is detected throughout all seasons, being highly significant in spring and summer. This means that for a given dynamical situation, according to ERA-Interim the annual mean temperature of the Arctic lower stratosphere has been cooling by $-0.41 \pm 0.11 \mathrm{Kdecade}^{-1}$ at $50 \mathrm{hPa}$ over the past $32 \mathrm{yr}$. Calculations with state-of-the-art models from CCMVal and the EMAC model qualitatively reproduce the radiatively induced
\end{abstract}

cooling for the past decades, but underestimate the amount of radiatively induced cooling deduced from reanalyses. There are indications that this discrepancy could be partly related to a possible underestimation of past Arctic ozone trends in the models. The models project a continued cooling of the Arctic stratosphere over the coming decades (2001-2049) that is for the annual mean about $40 \%$ less than the modeled cooling for the past, due to the reduction of ozone depleting substances and the resulting ozone recovery. This projected cooling in turn could offset between 15 and $40 \%$ of the Arctic ozone recovery.

\section{Introduction}

Large losses of Arctic stratospheric ozone have been observed during cold winters over the past decades (WMO, 2011). There is some evidence that the cold Arctic stratospheric winters are getting colder (Rex et al., 2004, 2006) with important implications for Arctic ozone depletion. In fact, the largest losses of Arctic stratospheric ozone have been observed in the recent winter 2010/2011 (Manney et al., 2011; Sinnhuber et al., 2011), despite the fact that the stratospheric halogen loading is already declining. Sinnhuber et al. (2011) calculated that a temperature trend of $-0.8 \mathrm{~K} \mathrm{decade}^{-1}$ could enhance Arctic stratospheric ozone depletion enough to offset the recovery due to the expected future halogen decrease. Although there are still uncertainties in the climate sensitivity of Arctic ozone depletion, the calculated temperature sensitivity agrees well with the empirical results of Rex et al. (2006). Moreover, the calculated value of 
$-0.8 \mathrm{Kdecade}^{-1}$ is close to the observed near-global $\left(60^{\circ} \mathrm{S}-\right.$ $60^{\circ} \mathrm{N}$ ) cooling of the lower stratosphere of $-0.5 \mathrm{Kdecade}^{-1}$ between 30 and $70 \mathrm{hPa}$ by Randel et al. (2009). However, the situation in the Arctic is more complicated due to the large influence of planetary scale waves on Arctic winter and spring temperatures (Newman et al., 2001) and corresponding large interannual variability. Temperature observations from the Stratospheric Sounding Unit (SSU) provide evidence that variations in wave driving are a major factor controlling global scale variability throughout the depth of the stratosphere (Young et al., 2011). Lower-stratospheric temperature observations from the Microwave Sounding Unit (MSU) indicate a strengthening of the Brewer-Dobson circulation (BDC) from December to February and a weakening from March until May connected to the increase/decrease of planetary wave activity, which leads to a corresponding positive/negative temperature trend ( $\mathrm{Fu}$ et al., 2010). Ray et al. (2010) suggest a small strengthening of the mean circulation in the lower stratosphere and a moderate weakening of the mean circulation of the middle and upper stratosphere. Trend calculations of an empirically derived BDCindex, which consists of the contrast between extra-tropical and tropical temperatures, suggest a significant strengthening of the Northern Hemisphere branch of the BDC during December throughout the depth of the stratosphere, and a significant weakening during March in the lower stratosphere (Young et al., 2012). Recently, Thompson et al. (2012) have emphasized the existing large uncertainties for past temperature trends from observations in the mid-stratosphere (25$50 \mathrm{~km}$ altitude). However, in the lower stratosphere (15$20 \mathrm{~km}$ ) Thompson et al. (2012) show good agreement between various satellite and radiosonde data sets, although most climate and chemistry-climate models underestimate the degree of this cooling. Lin et al. (2009) conclude that IPCC AR4 models fail to simulate the BDC strengthening in the southern polar stratosphere. In addition there are significant differences between measurements of mean age of air and CCM simulations (Ray et al., 2010). Wang and Waugh (2012) show that the variability in lower stratospheric temperature trends among model ensembles is related to differences in trends in wave activity propagating into the stratosphere.

In this study we analyze past and projected future temperature trends in the Arctic lower stratosphere. In particular, we investigate if, in addition to the highly variable wave activity in the Arctic, a secular temperature trend can be identified that could be attributed to changes in radiatively active gases. We focus on temperatures in the lower stratosphere at $50 \mathrm{hPa}$, as this is the region most critical for Arctic ozone depletion. Unless otherwise noted, we consider averages over $60-90^{\circ} \mathrm{N}$. We use reanalyses from the European Centre for Medium Range Weather Forecasts (ECMWF) ERA-Interim project (Dee et al., 2011) and NASA's Modern-Era Retrospective Analysis for Research and Applications (MERRA) (Rienecker et al., 2011) together with the Radiosonde In- novation Composite Homogenization (RICH) adjusted radiosonde data set (Haimberger et al., 2012) for the past $32 \mathrm{yr}$ to determine temperature trends (Sect. 2). After comparing state-of-the art model calculations from CCMVal2 (e.g., Morgenstern et al., 2010) with the past temperature trends from observations and reanalyses, these models are analyzed to project the evolution for coming decades (Sect. 3). CCMVal2 models are accompanied by additional calculations with the chemistry-climate model EMAC. Sensitivity simulations with EMAC using fixed mixing ratios of greenhouse gases (in particular $\mathrm{CO}_{2}, \mathrm{~N}_{2} \mathrm{O}, \mathrm{CH}_{4}$ ) and ozone depleting substances (ODS) are used to calculate the sensitivity of temperature changes to the respective radiatively active gases.

\section{Past Arctic temperature changes}

ECMWF ERA-Interim (Dee et al., 2011) and MERRA (Rienecker et al., 2011) reanalyses, together with RICH adjusted radiosonde data (Haimberger et al., 2012) from 1980-2011, are used to determine temperature trends. ERA-Interim data have been obtained from the ECMWF data server at a horizontal resolution of $1.5^{\circ} \times 1.5^{\circ}$. Temperature trends in the Arctic lower stratosphere are calculated, using daily mean temperature fields. The eddy heat flux, indicating planetary wave activity, is derived from daily temperature and wind fields at $100 \mathrm{hPa}$ over $45-75^{\circ} \mathrm{N}$ (Newman et al., 2001).

Figure 1a shows Arctic temperature changes at $50 \mathrm{hPa}$ for the period 1980 to 2011 calculated from ERAInterim, MERRA, and RICH observations. Values are given with a $2 \sigma$ error range, meaning a $95.4 \%$ confidence interval. Averaged over the year, there is cooling tendency of $-0.25 \pm 0.21 \mathrm{Kdecade}^{-1}$ in ERA-Interim. Summer months (JJA) show a significant cooling of $-0.42 \pm 0.13 \mathrm{Kdecade}^{-1}$. This value is close to the nearglobal $\left(60^{\circ} \mathrm{S}-60^{\circ} \mathrm{N}\right)$ temperature trend of $-0.5 \mathrm{Kdecade}^{-1}$ derived by Randel et al. (2009) in the lower stratosphere. Especially during summer, the Arctic stratosphere is in a state of radiative equilibrium (Newman and Rosenfield, 1997), which makes stratospheric temperature trends comparable to the near-global mean trend. Furthermore, there exists a strong significant cooling of $-1.02 \pm 0.58 \mathrm{Kdecade}^{-1}$ during spring (MAM). In contrast, winter months (DJF) show a mean warming trend of $0.62 \pm 1.06 \mathrm{Kdecade}^{-1}$, which is, however, not significant. Seasonal temperature trends from ERA-Interim and MERRA are consistent with trends from RICH adjusted radiosonde data and are given in Table 2.

The cooling in spring and warming in winter is consistent with a corresponding change in wave activity, expressed by the area-weighted average of the eddy heat flux at $100 \mathrm{hPa}$ over $45-75^{\circ} \mathrm{N}$ (Fig. 2), which is consistent with findings from Fu et al. (2010). There is high consistency between the monthly mean eddy heat flux from ERA-Interim and MERRA, with the differences between both reanalyses being much smaller than the statistical uncertainty. These changes 
$50 \mathrm{hPa} 60-90^{\circ} \mathrm{N} 1980-2011$

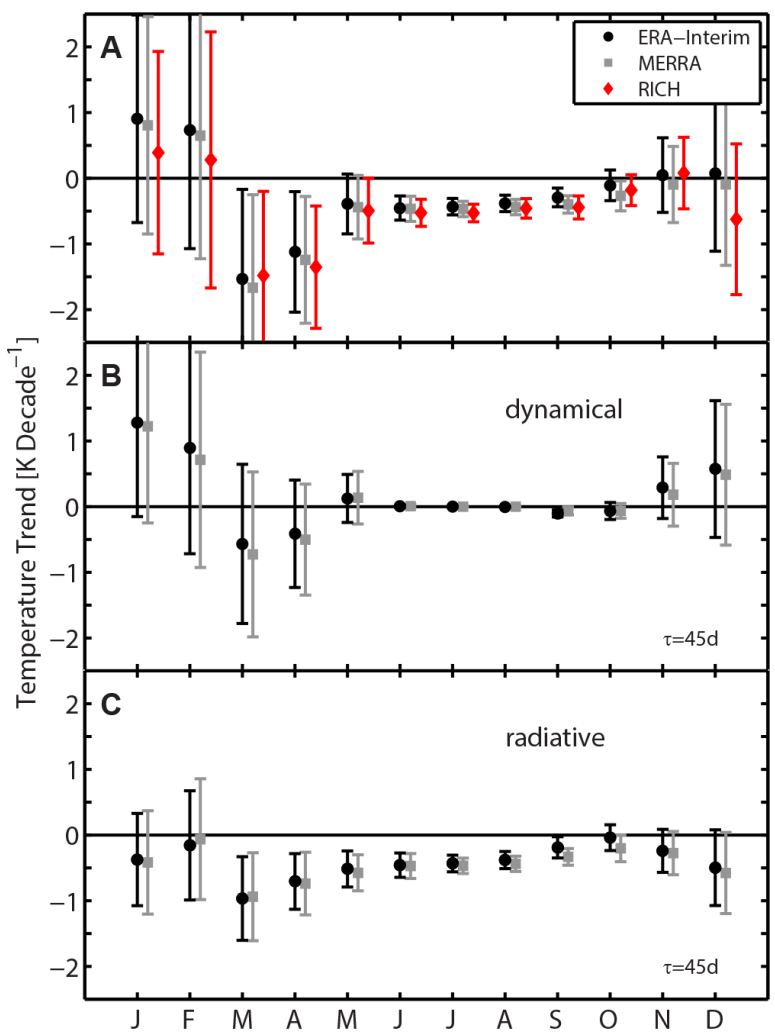

Fig. 1. Arctic temperature trends per decade at $50 \mathrm{hPa}$ for each month from ERA-Interim (black), MERRA (gray) and RICH adjusted radiosonde observations (red) for the years 1980-2011. The figure shows the area-weighted average over $60-90^{\circ} \mathrm{N}$. (A) Temperature trend. (B) Dynamical component of the trend. (C) Residual radiative component of the trend. Vertical bars show the $2 \sigma$ uncertainty.

in eddy heat flux thus lead to a dynamical contribution to long-term Arctic temperature trends. Although it is difficult to estimate the absolute accuracy of the eddy heat flux from reanalyses, the good agreement between ERA-Interim and MERRA provides confidence that the results are robust and errors dominated by the statistical uncertainty.

The correlations between temperature and eddy heat flux are high, exceeding $r=0.75$ for all relevant months (December to May). This is consistent with findings from Newman et al. (2001), showing a robust linear relationship between eddy heat flux changes and stratospheric temperature anomalies. Based on this relation we use a linear multivariate regression model to separate the effects on temperature changes due to dynamical processes, congruent with changes in the eddy heat flux and radiative processes that follow the long-term changes of radiatively active gases. For the multivariate regression applied to monthly mean temperatures we assume a linear trend term and a term referring to planetary

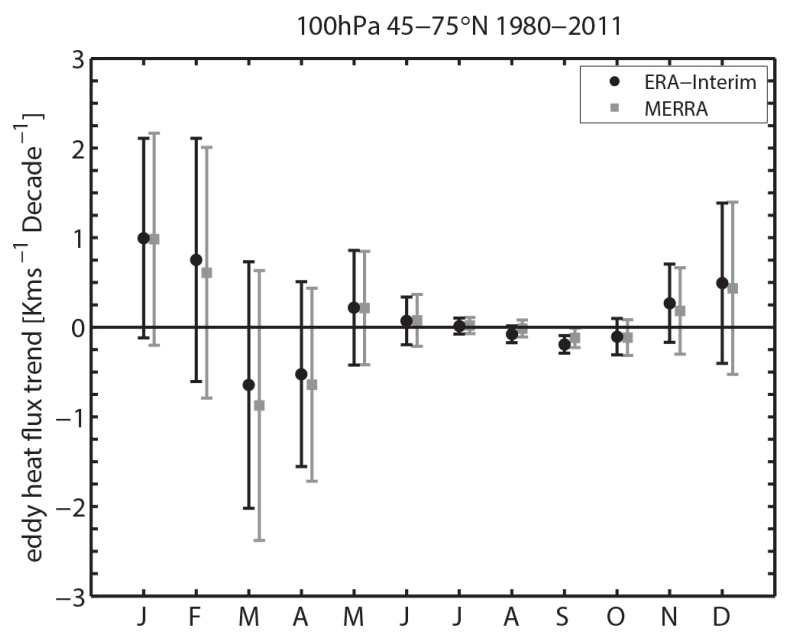

Fig. 2. Eddy heat flux trend at $100 \mathrm{hPa}$ from ERA-Interim (black) and MERRA (gray) data (1980-2011). The figure shows the areaweighted average over $45-75^{\circ} \mathrm{N}$. Mean trends are calculated from eddy heat flux averages over the previous 45 days. Vertical bars show the $2 \sigma$ uncertainty.

wave activity proportional to the eddy heat flux at $100 \mathrm{hPa}$ integrated over the previous 45 days. The 45 -day timescale corresponds to a typical radiative damping time at $50 \mathrm{hPa}$ (Newman and Rosenfield, 1997; Newman et al., 2001). Tests with different damping times between 30 and 60 days revealed the highest correlations between eddy heat flux and temperature anomalies for a damping time of around 45 days. The dynamical contribution to the temperature trend therefore corresponds to the trends in eddy heat flux, with the highest effect in winter and spring (Fig. 1b). The linear trend term represents the residual radiative contribution. Errors of the fit coefficients are estimated from the variance of the residuals.

The radiative contribution from ERA-Interim (Fig. 1c) shows cooling throughout the whole year with an annual mean cooling of $-0.41 \pm 0.11 \mathrm{Kdecade}^{-1}$, close to the cooling during summer, which is the same for the radiative contribution since planetary wave activity is low at that time. During winter the radiative contribution is negative $\left(-0.52 \pm 0.53 \mathrm{Kdecade}^{-1}\right)$, in contrast to the temperature trend mentioned above, which again shows the strong influence of planetary wave activity on lower stratospheric temperature in the Arctic. In spring, radiatively induced cooling is stronger compared to the other seasons and highly significant $\left(-0.76 \pm 0.35 \mathrm{Kdecade}^{-1}\right)$. Results from MERRA show essentially the same (Table 2).

Ozone depletion in spring is sensitive to temperatures throughout the whole winter period, from December to March (Rex et al., 2004; Sinnhuber et al., 2011). Therefore we also investigate extended winter mean (DJFM) trends. Extended winter means show radiative mean cooling of $-0.52 \pm 0.49 \mathrm{Kdecade}^{-1}$. Thus, for a given level of wave activity, mean winter temperatures have been getting colder 
over the past three decades by $-0.52 \pm 0.49 \mathrm{Kdecade}^{-1}$. Again, this is comparable to the near-global mean cooling of about $-0.5 \mathrm{Kdecade}^{-1}$ at this level from ERA-Interim (Table 3 ) and radiosonde observations (Randel et al., 2009).

\section{Results from chemistry-climate models}

\subsection{Model description}

To investigate if and how the inferred past cooling is expected to continue into the future, we analyze results from 18 chemistry-climate model (CCM) simulations, performed as part of the second Chemistry-Climate Model Validation Activity (CCMVal2) (SPARC CCMVal, 2010). CCMVal2 model simulations (Morgenstern et al., 2010) used in this study refer to two sets of forcings, REF-B2 and SCN-B2d. REF-B2 models use greenhouse gas concentrations from A1B scenario (IPCC, 2000, 2007). Sea surface temperatures (SST) and sea ice concentrations (SIC) are simulated through previous offline model calculations. SCN-B2d additionally include volcanic eruptions, solar variability and a prescribed quasi-biennial oscillation (QBO) of equatorial winds. Further information about CCMVal2 forcings can be found in the SPARC CCMVal (2010) report. For this study we use CCMVal2 model simulations listed in Table 1. Only models that reported monthly mean $100 \mathrm{hPa}$ eddy heat flux based on daily fields are included. For the multivariate regression we use a mean of the eddy heat flux at $100 \mathrm{hPa}$, consisting of the current and previous month, which provides results similar to calculations with a damping time of 45 days.

In addition to CCMVal2 model simulations we performed further calculations with the ECHAM/MESSy Atmospheric Chemistry Model (EMAC). We use the Modular Earth Submodel System (MESSy, version 1.7) (Jöckel et al., 2005, 2006) in combination with ECHAM5 (Roeckner et al., 2006) as our base model.

EMAC simulations were performed with a T42 horizontal resolution (about $2.8^{\circ}$ ) and 39 vertical levels with the uppermost level at $0.01 \mathrm{hPa}$. EMAC configurations follow the REF-B2 forcings and are briefly described in the following. SSTs and SICs were taken from a previous coupled simulation of the ECHAM5 climate model with the ocean model MPI-OM from Max-Planck-Institute in Hamburg. The A1B scenario (IPCC, 2000, 2007) was applied in the EMAC simulation. Volcanic eruptions, solar variability and QBO were not included, in accordance with REF-B2 specifications.

In this study, we focus on two periods. The first period is from 1980 to 2011 and the second from 2001 to 2049. The first period was chosen to allow a direct comparison with ERA-Interim. For future trends a starting point around 2000 is reasonable since the stratospheric halogen loading reached its maximum around that point and has been decreasing ever since (Kohlhepp et al., 2012). In the future, referring to A1B scenario, halogens continue to decrease. Choosing this pe-
Table 1. Model calculations used in this study. Only CCMVal2 models that reported $100 \mathrm{hPa}$ eddy heat flux are included. Numbers in parentheses indicate number of ensemble members included.

\begin{tabular}{l}
\hline CCMVal2 REF-B2 model runs \\
\hline CCSRNIES (1) \\
CMAM (3) \\
GEOSCCM (1) \\
LMDZepro (1) \\
MRI (2) \\
Niwa SOCOL (1) \\
SOCOL (3) \\
ULAQ (3) \\
UMUKCA-METO (1) \\
\hline CCMVal2 SCN-B2d model runs \\
\hline E39CA (1) \\
EMAC-FUB (1) \\
\hline Additional EMAC runs \\
\hline EMAC REF-B2 standard run (1) \\
EMAC GHGs constant after $2000(1)$ \\
EMAC CO 2 constant after $2000(1)$ \\
EMAC CH CH $_{4}$ constant after $2000(1)$ \\
EMAC $\mathrm{N}_{2} \mathrm{O}$ constant after $2000(1)$ \\
EMAC ODSs constant after $2000(1)$ \\
\hline
\end{tabular}

riod (2001-2049) enables the maximum halogen effect to become visible.

\subsection{Reproducing the past}

Figure $3 \mathrm{a}-\mathrm{c}$ shows results from CCMVal2 simulations for 1980-2011, which can be directly compared to Fig. 1. Each black dot represents a single CCMVal2 model simulation with the black line being the multi-model mean over all CCMVal2 simulations. We do not find any distinct differences in temperature trends between REF-B2 and SCN-B2d, justifying the inclusion of both sets into the calculation of the multi-model mean. Our EMAC simulations, however, were not included in the multi-model mean.

Most CCMVal2 models show a cooling tendency in spring and summer (Fig. 3a), which is consistent with temperature trends from reanalyses and radiosonde data (Fig. 1a). In winter and early spring, however, there is a wide spread of the models, reflecting large internal variability in these months.

The dynamical component (Fig. 3b) shows no clear overall tendency but a wide spread of the participating models. No clear strengthening of the $45-75^{\circ} \mathrm{N} 100 \mathrm{hPa}$ eddy heat flux in the last three decades can be identified, but the multi-model mean shows some indications of an increased eddy heat flux in early winter (January) and a decreased eddy heat flux in March, consistent with the findings of Fu et al. (2010) and Young et al. (2012). 
50hPa $60-90^{\circ} \mathrm{N} 1980-2011$

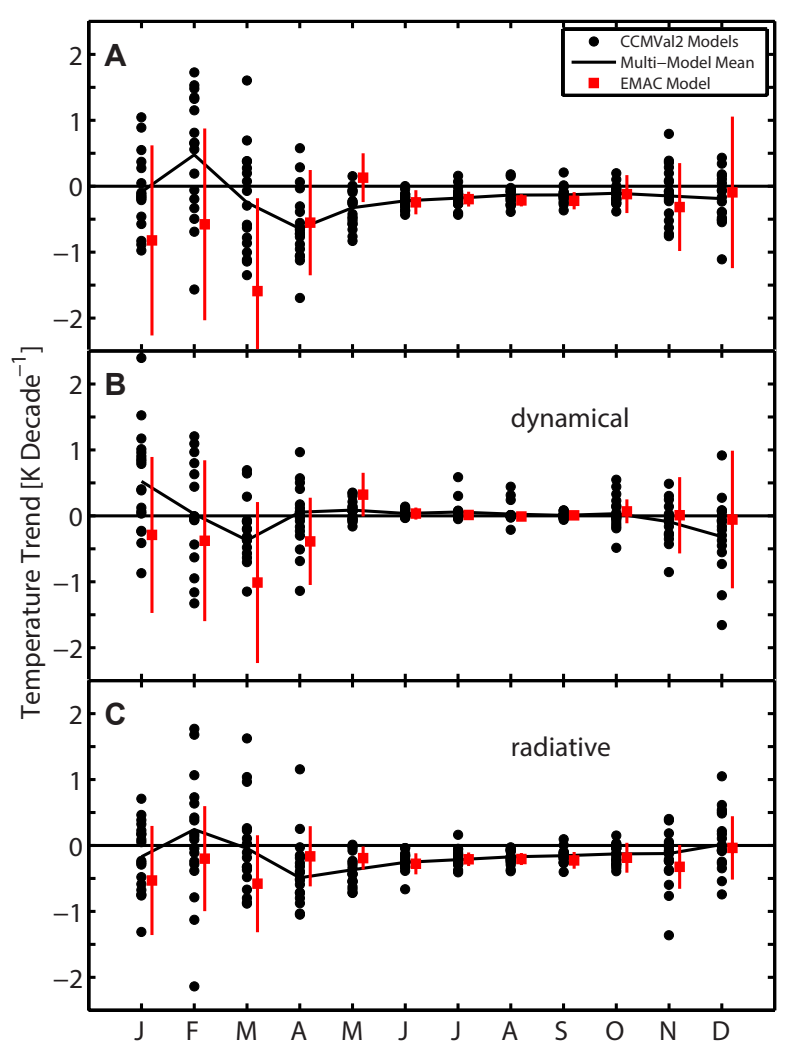

Fig. 3. Arctic temperature trends per decade at $50 \mathrm{hPa}$ for each month from EMAC (red) and CCMVal2 models (black) for the years 1980-2011. The figure shows the area-weighted average over $60-90^{\circ}$ N. (A) Temperature trend. (B) Dynamical component of the trend. (C) Residual radiative component of the trend. Vertical bars show the $2 \sigma$ uncertainty.

The radiative contribution to temperature trends indicates a cooling tendency $\left(-0.16 \pm 0.04 \mathrm{Kdecade}^{-1}\right)$ of the CCMVal2 multi-model mean averaged over the year (Fig. 3c), which is even stronger in summer $\left(-0.22 \pm 0.02 \mathrm{Kdecade}^{-1}\right)$. The error on the multi-model mean is not shown in the figure. However, most CCMVal2 models underestimate observed temperature trends, which is qualitatively consistent with findings from Thompson et al. (2012). The CCMVal2 multi-model mean shows about half of the radiatively induced cooling of ERA-Interim and MERRA. The spread of the models is smaller compared to Fig. 3a, which is due to the missing variable dynamical contribution.

Our EMAC simulation is not part of the multi-model mean but shows a general agreement with most of the CCMVal2 models (Fig. 3). The variability of the EMAC model, displayed by the error bars, is comparable to ERA-Interim and MERRA. In contrast to the reanalyses, the dynamical and ra- diative contribution in EMAC have the same sign (Fig. 3b, c) during winter for 1980-2011; both contribute to a cooling.

EMAC shows a significant radiatively induced annual mean cooling of $-0.26 \pm 0.11 \mathrm{Kdecade}^{-1}$. In fact, there is a cooling trend in all seasons (Table 2), however, underestimating the cooling in the reanalyses. The cooling is significant for all seasons but winter. The strongest cooling occurs in spring, which is consistent with observations.

\subsection{The role of ozone trends}

To test if the discrepancy between observed and modeled temperature trends, in particular during Arctic summer, can be explained by differences between observed and modeled ozone trends over the past decades, we compare Arctic ozone trends from the CCMVal2 models and our EMAC calculations with observational-based ozone trends from Randel and $\mathrm{Wu}$ (2007). Figure 4 compares monthly mean modeled and observed ozone trends over the period 1979-2005. While the shape of the ozone trends is similar between the models and the observed trend with maximum losses in spring and smallest trends in summer and autumn, the models underestimate the observed trend, with the largest relative differences in summer. There is a relatively large scatter between the different models, with our EMAC calculation close to the multi-model mean. However, it should be noted that the lower stratospheric ozone trends poleward of $60^{\circ} \mathrm{N}$ in the Randel and $\mathrm{Wu}$ (2007) data set are based on data from only a single ozone sonde station and are thus themselves subject to considerable systematic uncertainty.

Future ozone trends from the models are shown in Fig. 5, all showing a future increase in Arctic ozone of similar magnitude as the past decline.

It thus seems possible that the discrepancy between observed and modeled temperature trends during Arctic summer is partly related to a possible underestimate of past Arctic ozone trends in the models.

\subsection{Predicted future Arctic temperature changes}

Future (2001-2049) temperature changes from the CCMVal2 and EMAC simulations are shown in Fig. 6a-c (similar to Figs. 1 and 3). Note that Fig. 6b, c have a different scale. CCMVal2 models show no clear temperature change in the future in any season (Fig. 6a). However, in summer there is a slight cooling indicated by the multi-model mean, but in each month models show both cooling and warming. Figure $6 \mathrm{~b}$ shows again a large spread of the CCMVal2 models when calculating the effect of planetary wave activity on the lower stratospheric temperature in the Arctic (Fig. 3b). The multi-model mean shows a slight positive dynamical contribution, but it is not significant. Considering only the radiative contribution the CCMVal2 multi-model mean for the future shows an annual cooling tendency of 
Table 2. Arctic temperature trends $\left(60-90^{\circ} \mathrm{N}\right)$ at $50 \mathrm{hPa}$ from $\mathrm{RICH}$ adjusted radiosonde data, ERA-Interim and MERRA reanalyses and model simulations. Seasonal temperature trends (overall) are shown for RICH, ERA-Interim and MERRA. The radiative contribution to the temperature trend is shown for ERA-Interim, MERRA, CCMVal2 multi-model mean and our EMAC simulation. All values are in K decade ${ }^{-1}$ with a $2 \sigma$ error range.

\begin{tabular}{lrrrrr}
\hline Data set & DJF & MAM & JJA & SON & Annual \\
\hline 1980-2011 & & & & & \\
\hline RICH (observed) & $+0.01 \pm 0.89$ & $-1.11 \pm 0.52$ & $-0.50 \pm 0.09$ & $-0.18 \pm 0.18$ & $-0.45 \pm 0.21$ \\
ERA-Interim (overall) & $+0.63 \pm 1.06$ & $-1.02 \pm 0.58$ & $-0.42 \pm 0.13$ & $-0.12 \pm 0.22$ & $-0.25 \pm 0.21$ \\
MERRA (overall) & $+0.52 \pm 1.12$ & $-1.12 \pm 0.59$ & $-0.46 \pm 0.12$ & $-0.25 \pm 0.21$ & $-0.34 \pm 0.22$ \\
ERA-Interim (radiative) & $-0.52 \pm 0.53$ & $-0.76 \pm 0.35$ & $-0.42 \pm 0.13$ & $-0.11 \pm 0.16$ & $-0.41 \pm 0.11$ \\
MERRA (radiative) & $-0.52 \pm 0.59$ & $-0.77 \pm 0.36$ & $-0.46 \pm 0.12$ & $-0.24 \pm 0.16$ & $-0.46 \pm 0.12$ \\
EMAC (radiative) & $-0.26 \pm 0.52$ & $-0.44 \pm 0.36$ & $-0.24 \pm 0.10$ & $-0.25 \pm 0.19$ & $-0.26 \pm 0.11$ \\
CCMVal2 (radiative) & $-0.03 \pm 0.08$ & $-0.30 \pm 0.11$ & $-0.22 \pm 0.02$ & $-0.14 \pm 0.05$ & $-0.16 \pm 0.04$ \\
\hline 2001-2049 & & & & & \\
\hline EMAC (radiative) & $-0.26 \pm 0.37$ & $+0.11 \pm 0.21$ & $-0.15 \pm 0.05$ & $-0.31 \pm 0.10$ & $-0.15 \pm 0.06$ \\
CCMVal2 (radiative) & $-0.17 \pm 0.04$ & $-0.03 \pm 0.06$ & $-0.08 \pm 0.01$ & $-0.13 \pm 0.02$ & $-0.10 \pm 0.02$ \\
\hline
\end{tabular}

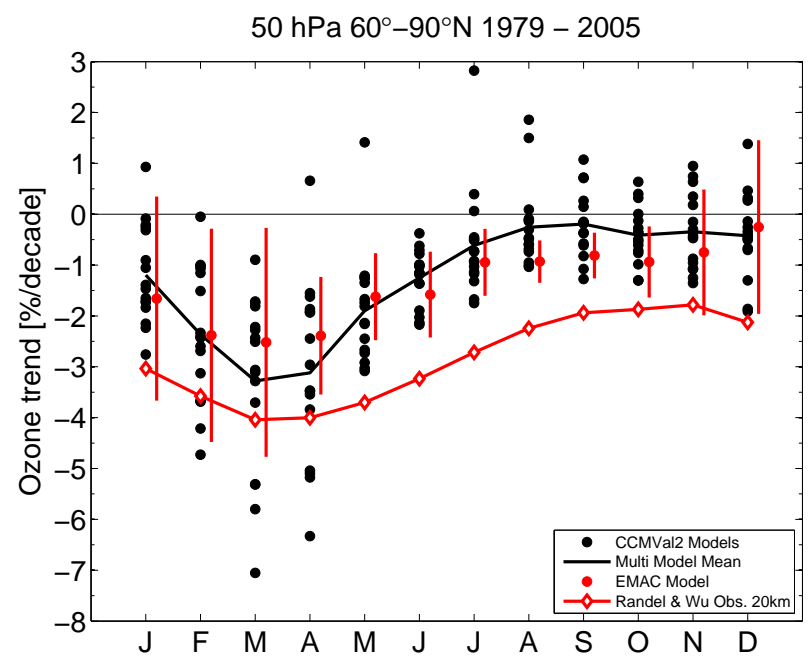

Fig. 4. Arctic ozone trends at 50hPa between 1979 and 2005 from CCMVal2 models (black dots), EMAC model (red dots with error bars) and observed ozone trends from Randel and Wu (2007) (red line with diamonds).

$-0.10 \pm 0.02 \mathrm{Kdecade}^{-1}$, which is about $40 \%$ smaller than the CCMVal2 multi-model mean for the past (1980-2011).

Our EMAC simulation shows cooling in summer, autumn and winter (Table 2), whereas in spring, there is a slight warming tendency. Annually averaged, there exists a cooling tendency of $-0.10 \pm 0.11 \mathrm{Kdecade}^{-1}$. The dynamical component has no clear trend but contributes to warming in January until March and to cooling in December. As expected, these months are most affected by planetary wave activity in EMAC.

Compared to the period from 1980 to 2011, the radiative component shows a smaller but significant

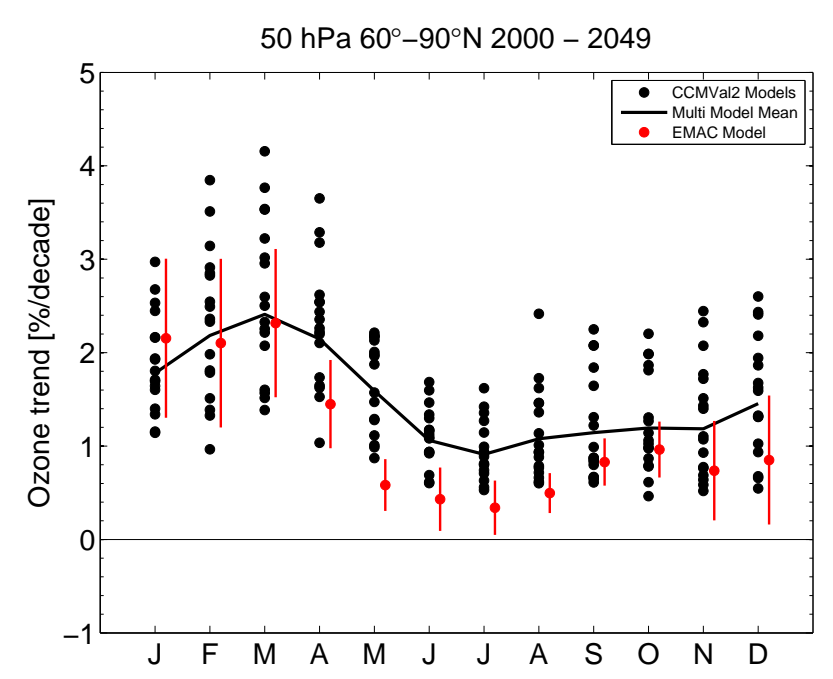

Fig. 5. As Fig. 4 but for the period 2000-2049.

cooling tendency with an annual temperature trend of $-0.15 \pm 0.06 \mathrm{Kdecade}^{-1}$. The mean radiatively induced cooling in winter months has become clearer and continues into the future with $-0.26 \pm 0.37 \mathrm{Kdecade}^{-1}$. In summer, trends become smaller compared to the past and decrease to $-0.15 \pm 0.05 \mathrm{Kdecade}^{-1}$, while temperature changes in spring are slightly positive (Table 2 ).

\subsection{Sensitivity study}

In total, six EMAC simulations were performed. In addition to the standard simulation (EMAC STD) described above, five sensitivity simulations were calculated. In four simulations, surface mixing ratios of ODS (EMAC ODS), $\mathrm{CO}_{2}$ (EMAC CO2), $\mathrm{N}_{2} \mathrm{O}$ (EMAC N2O) and $\mathrm{CH}_{4}$ (EMAC CH4) are held constant for the period 2000 to 2049. One simulation 
50hPa $60-90^{\circ} \mathrm{N} 2001-2049$

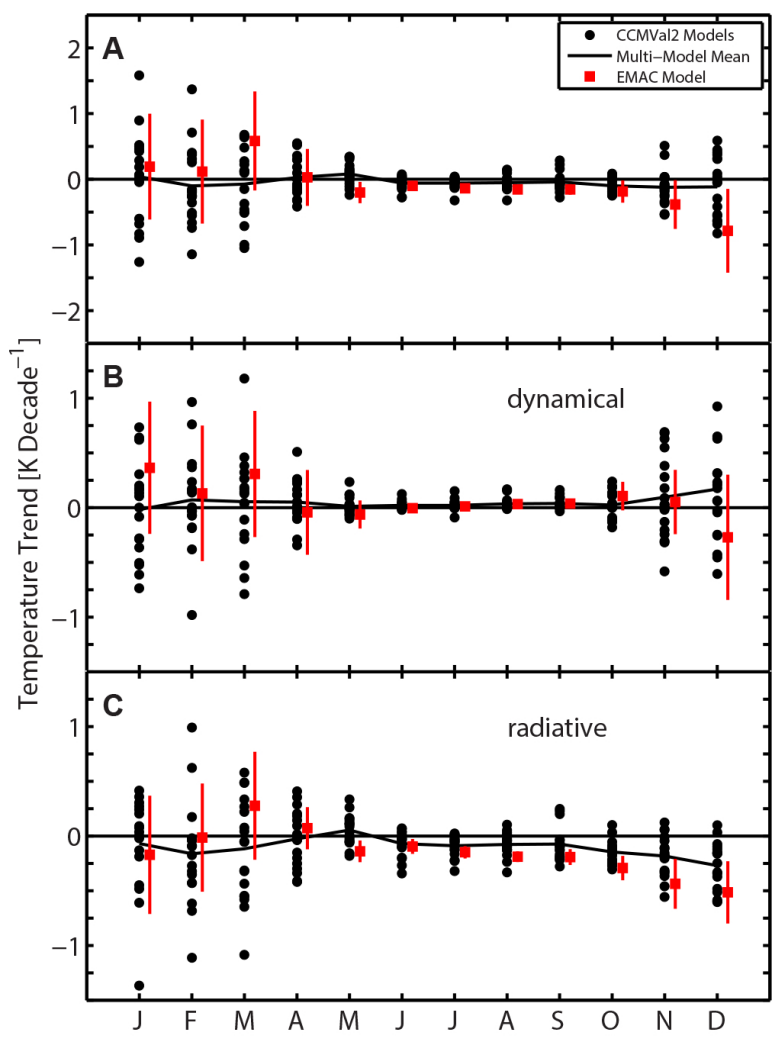

Fig. 6. Arctic temperature trends per decade at $50 \mathrm{hPa}$ for each month from EMAC (red) and CCMVal2 models (black) for the years 2001-2049. The figure shows the area-weighted average over $60-90^{\circ}$ N. (A) Temperature trend. (B) Dynamical component of the trend. (C) Residual radiative component of the trend. Vertical bars show the $2 \sigma$ uncertainty. Note the different scale for $(\mathbf{B})$ and $(\mathbf{C})$.

was driven with all three major greenhouse gases $\left(\mathrm{CO}_{2}, \mathrm{~N}_{2} \mathrm{O}\right.$ and $\mathrm{CH}_{4}$ ) fixed after 2000 (EMAC GHG). The simulations with fixed trace gases are initialized with data from the standard simulation for the year 2000 .

Note that there is full chemical, radiative and dynamical feedback in the simulations. For example, $\mathrm{N}_{2} \mathrm{O}$ not only acts as a greenhouse gas but also as a source of $\mathrm{NO}_{\mathrm{y}}$ affecting ozone chemistry. Similarly, $\mathrm{CH}_{4}$ has direct radiative effects and affects stratospheric water and ozone chemistry. In all simulations, changes in stratospheric temperatures affect ozone concentrations.

Table 3 summarizes the calculated global mean temperature trends from the sensitivity simulations. Keeping $\mathrm{CO}_{2}$ constant after 2000 reduces the global mean annual mean cooling in the EMAC simulation from $-0.30 \pm 0.02 \mathrm{Kdecade}^{-1}$ to only $-0.10 \pm 0.03 \mathrm{Kdecade}^{-1}$. Keeping $\mathrm{CH}_{4}$ and $\mathrm{N}_{2} \mathrm{O}$ constant also leads to a reduced cooling, but the effect is smaller than for $\mathrm{CO}_{2}$. Fixing $\mathrm{CO}_{2}, \mathrm{CH}_{4}$ and $\mathrm{N}_{2} \mathrm{O}$ together leads to calculated future global mean an-
Table 3. Global temperature trends at $50 \mathrm{hPa}$ from ERA-Interim reanalyses and model simulations. All values are in $\mathrm{Kdecade}^{-1}$ with a $2 \sigma$ error range.

\begin{tabular}{lr}
\hline Data set & Annual mean trend \\
\hline $1980-2011$ & \\
\hline ERA-Interim & $-0.46 \pm 0.05$ \\
EMAC & $-0.314 \pm 0.004$ \\
CCMVal2 & \\
\hline $2001-2049$ & $-0.30 \pm 0.02$ \\
\hline EMAC $(\mathrm{STD})$ & $-0.224 \pm 0.002$ \\
CCMVal2 & $-0.32 \pm 0.02$ \\
EMAC const. ODS & $-0.10 \pm 0.03$ \\
EMAC const CO & $-0.28 \pm 0.02$ \\
EMAC const. $\mathrm{N}_{2} \mathrm{O}$ & $-0.24 \pm 0.03$ \\
EMAC const. CH & $-0.06 \pm 0.02$ \\
EMAC const. $\mathrm{GHGs}_{4}$ & \\
\hline
\end{tabular}

nual mean cooling of only $-0.06 \pm 0.02 \mathrm{Kdecade}^{-1}$. In contrast, fixing the ODS at their 2000 level, while increasing the greenhouse gases as in the base run, leads to a future cooling of $-0.32 \pm 0.02 \mathrm{Kdecade}^{-1}$. Thus in EMAC future stratospheric temperature trends are predominantly influenced by the increase of greenhouse gases and to a much lesser extent by the decline of ODS. Note that the individual contributions are nearly linearly additive, taking into account the temperature trend uncertainties. For the Arctic, the large internal variability results in less significant trends for the sensitivity calculations.

\section{Conclusions}

We investigated past and possible future Arctic stratospheric temperature trends using ERA-Interim and MERRA reanalyses together with RICH-adjusted radiosonde data, $\mathrm{CCM}$ calculations from the CCMVal2 project and additional calculations with the EMAC model with a focus on $50 \mathrm{hPa}$ and averages over $60-90^{\circ} \mathrm{N}$.

Arctic temperature trends over 1980-2011 from observations and reanalyses show a warming in winter and cooling in spring and summer. The warming in winter and the cooling in spring are consistent with a corresponding change in eddy heat flux with increases in winter and reductions in early and mid-spring.

Using multivariate regression, we separate temperature changes into a dynamical component, congruent with changes in planetary wave activity, and a residual radiative component that cannot be accounted for by the linear regression of planetary wave activity upon temperature. We find that for a given level of eddy heat flux, there is a signifcant annual mean radiatively induced cooling in ERA-Interim and MERRA of $-0.41 \pm 0.11 \mathrm{Kdecade}^{-1}$ and 
$-0.46 \pm 0.12 \mathrm{Kdecade}^{-1}$, respectively, similar to the global mean cooling at $50 \mathrm{hPa}$ (Randel et al., 2009). Moreover, the radiative contribution shows Arctic cooling in all months.

CCM calculations from CCMVal2 and EMAC qualitatively reproduce the past radiatively induced cooling tendency. However, EMAC underestimates annual radiatively induced cooling compared to the reanalyses $\quad\left(-0.26 \pm 0.11 \mathrm{Kdecade}^{-1}\right)$, while the CCMVal2 multi-model mean shows even less cooling $\left(-0.16 \pm 0.04 \mathrm{Kdecade}^{-1}\right)$. It seems possible that at least part of the discrepancy between observed and modeled temperature trends during Arctic summer are related to a possible underestimate of past Arctic ozone trends in the models.

Calculations over the period 2001-2049 show continued cooling but less than for the past. EMAC and the CCMVal2 multi-model mean expect the future radiative annual cooling to be about $40 \%$ less compared to the past $\left(-0.15 \pm 0.06 \mathrm{Kdecade}^{-1}\right.$ and $-0.10 \pm 0.02 \mathrm{Kdecade}^{-1}$, respectively). Sensitivity calculations with the EMAC model show that the cooling of the lower stratosphere at around $50 \mathrm{hPa}$ will be largely controlled by changes in greenhouse gases, most importantly $\mathrm{CO}_{2}$, with reductions in ODS playing only a minor role for projected temperature trends.

Multi-model projections of Arctic ozone show an accelerated recovery over the next decades due to the increase of greenhouse gases (Eyring et al., 2010). However, Sinnhuber et al. (2011) calculated that a cooling of the Arctic winter stratosphere by about $0.8 \mathrm{Kdecade}^{-1}$ could fully offset expected Arctic ozone recovery due to the reduction of ODS by enhancing chemical ozone depletion in cold winters. Based on the observed cooling over the past decades and the projected reduction of the cooling rate for the future from the CCM calculations, we would arrive at a projected radiatively induced cooling of the Arctic winter lower stratosphere of about $0.3 \mathrm{Kdecade}^{-1}$. This cooling could thus counteract $30-$ $40 \%$ of the expected ozone recovery due to the reduction of ODS. The projected cooling from the CCMVal2 models itself is smaller than this value, with projected temperature trends ranging from $-0.1 \mathrm{Kdecade}^{-1}$ for the annual mean to $-0.17 \mathrm{Kdecade}^{-1}$ for DJF. This would correspond to offsetting between about 15 to $20 \%$ of the expected ozone recovery due to reduction of ODS. Future work should address the discrepancy between observed and modeled temperature changes in the lower stratosphere over the past decades, and its possible relation to past ozone trends, to better constrain the projected future cooling of the Arctic lower stratosphere, which is essential to project future Arctic ozone recovery.
Acknowledgements. Parts of this work were supported by the German Helmholtz Association through its research programme "Atmosphere and Climate" (ATMO) and the Deutsche Forschungsgemeinschaft (DFG) through the Research Unit SHARP. ERA-Interim reanalyses were provided through the ECMWF data server. We acknowledge the modeling groups for making their simulations available for this analysis, the ChemistryClimate Model Validation (CCMVal) Activity for WCRP's (World Climate Research Programme) SPARC (Stratospheric Processes and their Role in Climate) project for organizing and coordinating the model data analysis activity, and the British Atmospheric Data Center (BADC) for collecting and archiving the CCMVal model output.

The service charges for this open access publication have been covered by a Research Centre of the Helmholtz Association.

Edited by: T. J. Dunkerton

\section{References}

Dee, D. P., Uppala, S. M., Simmons, A. J., Berrisford, P., Poli, P., Kobayashi, S., Andrae, U., Balmaseda, M. A., Balsamo, G., Bauer, P., Bechtold, P., Beljaars, A. C. M., van de Berg, L., Bidlot, J., Bormann, N., Delsol, C., Dragani, R., Fuentes, M., Geer, A. J., Haimberger, L., Healy, S. B., Hersbach, H., Hólm, E. V., Isaksen, L., Kållberg, P., Köhler, M., Matricardi, M., McNally, A. P., Monge-Sanz, B. M., Morcrette, J.-J., Park, B.K., Peubey, C., de Rosnay, P., Tavolato, C., Thépaut, J.-N., and Vitart, F.: The ERA-Interim reanalysis: configuration and performance of the data assimilation system, Q. J. R. Meteor. Soc., 137, 553-597, 2011.

Eyring, V., Cionni, I., Bodeker, G. E., Charlton-Perez, A. J., Kinnison, D. E., Scinocca, J. F., Waugh, D. W., Akiyoshi, H., Bekki, S., Chipperfield, M. P., Dameris, M., Dhomse, S., Frith, S. M., Garny, H., Gettelman, A., Kubin, A., Langematz, U., Mancini, E., Marchand, M., Nakamura, T., Oman, L. D., Pawson, S., Pitari, G., Plummer, D. A., Rozanov, E., Shepherd, T. G., Shibata, K., Tian, W., Braesicke, P., Hardiman, S. C., Lamarque, J. F., Morgenstern, O., Pyle, J. A., Smale, D., and Yamashita, Y.: Multimodel assessment of stratospheric ozone return dates and ozone recovery in CCMVal-2 models, Atmos. Chem. Phys., 10, 94519472, doi:10.5194/acp-10-9451-2010, 2010.

Fu, Q., Solomon, S., and Lin, P.: On the seasonal dependence of tropical lower-stratospheric temperature trends, Atmos. Chem. Phys., 10, 2643-2653, doi:10.5194/acp-10-2643-2010, 2010.

Haimberger, L., Tavolato, C., and Sperka, S.: Homogenization of the global radiosonde temperature dataset through combined caomparison with reanalysis background series and neighbouring stations, J. Clim., 25, 8108-8131, 2012.

IPCC 2000, N. Nakicenovic and R. Swart (Eds.): Emission Scenarios, Cambridge University Press, UK, Cambridge, England, 570 pp., 2000.

IPCC 2007, Solomon, S., Qin, D., Manning, M., Marquis, M., Averyt, K., Tignor, M. M. B. and Miller, H. L. (Eds.): Climate Change 2007: Physical Science Basis. Contribution of Working Group I to the Fourth Assessment Report of the Intergovernmen- 
tal Panel on Climate Change, Cambridge University Press, Cambridge, England, 2007.

Jöckel, P., Sander, R., Kerkweg, A., Tost, H., and Lelieveld, J.: Technical Note: The Modular Earth Submodel System (MESSy) - a new approach towards Earth System Modeling, Atmos. Chem. Phys., 5, 433-444, doi:10.5194/acp-5-433-2005, 2005.

Jöckel, P., Tost, H., Pozzer, A., Brühl, C., Buchholz, J., Ganzeveld, L., Hoor, P., Kerkweg, A., Lawrence, M. G., Sander, R., Steil, B., Stiller, G., Tanarhte, M., Taraborrelli, D., van Aardenne, J., and Lelieveld, J.: The atmospheric chemistry general circulation model ECHAM5/MESSy1: consistent simulation of ozone from the surface to the mesosphere, Atmos. Chem. Phys., 6, 50675104, doi:10.5194/acp-6-5067-2006, 2006.

Kohlhepp, R., Ruhnke, R., Chipperfield, M. P., De Mazière, M., Notholt, J., Barthlott, S., Batchelor, R. L., Blatherwick, R. D., Blumenstock, Th., Coffey, M. T., Demoulin, P., Fast, H., Feng, W., Goldman, A., Griffith, D. W. T., Hamann, K., Hannigan, J. W., Hase, F., Jones, N. B., Kagawa, A., Kaiser, I., Kasai, Y., Kirner, O., Kouker, W., Lindenmaier, R., Mahieu, E., Mittermeier, R. L., Monge-Sanz, B., Morino, I., Murata, I., Nakajima, H., Palm, M., Paton-Walsh, C., Raffalski, U., Reddmann, Th., Rettinger, M., Rinsland, C. P., Rozanov, E., Schneider, M., Senten, C., Servais, C., Sinnhuber, B.-M., Smale, D., Strong, K., Sussmann, R., Taylor, J. R., Vanhaelewyn, G., Warneke, T., Whaley, C., Wiehle, M., and Wood, S. W.: Observed and simulated time evolution of $\mathrm{HCl}, \mathrm{ClONO}_{2}$, and $\mathrm{HF}$ total column abundances, Atmos. Chem. Phys., 12, 3527-3556, doi:10.5194/acp12-3527-2012, 2012.

Lin, P., Fu, Q., and Solomon, S.: Temperature trend patterns in southern hemisphere high latitudes: Novel indicators of stratospheric change, J. Clim., 22, 6325-6340, 2009.

Manney, G. L., Santee, M. L., Rex, M., Livesey, N. J., Pitts, M. C., Veefkind, P., Nash, E. R., Wohltmann, I., Lehmann, R., Froidevaux, L., Poole, L. R., Schoeberl, M. R., Haffner, D. P., Davies, J., Dorokhov, V., Gernandt, H., Johnson, B., Kivi, R., Kyrö, E., Larsen, N., Levelt, P. F., Makshtas, A., McElroy, C. T., Nakajima, H., Parrondo, M. C., Tarasick, D. W., von der Gathen, P., Walker, K. A., and Zinoviev, N. S.: Unprecedented Arctic ozone loss in 2011, Nature, 478, 469-475, doi:10.1038/nature10556, 2011.

Morgenstern, O. Giorgetta, M. A., Shibata, K., Eyring, V., Waugh, D. W., Shepherd, T. G., et al.: Review of the formulation of present-generation stratospheric chemistry-climate models and associated external forcings, J. Geophys. Res., 115, D00M02, doi:10.1029/2009JD013728, 2010.

Newman, P. A. and Rosenfield, J. E.: Stratospheric thermal damping times, Geophys. Res. Lett., 24, 433-436, 1997.

Newman, P. A., Nash, E. R., and Rosenfield, J. E.: What controls the temperature of the Arctic stratosphere in March?, J. Geophys. Res., 106, 19999-20010, 2001.

Randel, W. J. and Wu, F.: A stratospheric ozone profile data set fro 1979-2005: Variability, trends and comparisons with column ozone data, J. Geophys. Res., 112, D02107, doi:10.1029/2006JD007339, 2007.

Randel, W. J., Shine, K. P., Austin, J., Barnett, J., Claud, C., Gillett, N. P., Keckhut, P., Langematz, U., Lin, R., Long, C., Mears, C., Miller, A., Nash, J., Seidel, D. J., Thompson, D. W. J., Wu, F., and Yoden, S.: An update of observed stratospheric temperature trends, J. Geophys. Res., 114, D02107, doi:10.1029/2008JD010421, 2009.
Ray, E. A., Moore, F. L., Rosenlof, K. H., Davis, S. M., Boenisch, H., Morgenstern, O., Smale, D., Rozanov, E., Hegglin, M., Pitari, G., Mancini, E., Braesicke, P., Butchart, N., Hardiman, S., Li, F., Shibata, K., and Plummer, D. A.: Evidence for changes in stratospheric transport and mixing over the past three decades based on multiple data sets and tropical leaky pipe analysis, J. Geophys. Res., 115, D21304, doi:10.1029/2010JD014206, 2010.

Rex, M., Salawitch, R. J., von der Gathen, P., Harris, N. R. P., Chipperfield, M. P., and Naujokat, B.: Arctic ozone loss and climate change, Geophys. Res. Lett., 31, L04116, doi:10.1029/2003GL018844, 2004.

Rex, M., Salawitch, R. J., Deckelmann, H., von der Gathen, P., Harris, N. R. P., Chipperfield, M. P., Naujokat, B., Reimer, E., Allaart, M., Andersen, S. B., Bevilacqua, R., Braathen, G. O., Claude, H., Davies, J., De Backer, H., Dier, H., Dorokhov, V., Fast, H., Gerding, M., Godin-Beekmann, S., Hoppel, K., Johnson, B., Kyrö, E., Litynska, Z., Moore, D., Nakane, H., Parrondo, M. C., Risley Jr., A. D., Skrivankova, P., Stübi, R., Viatte, P., Yushkov, V., and Zerefos, C.: Arctic winter 2005: implications for stratospheric ozone loss and climate change, Geophys. Res. Lett., 33, L23808, doi:10.1029/2006GL026731, 2006.

Rienecker, M. M., Suarez, M. J., Gelaro, R., Todling, R., Bacmeister, J., Liu, E., Bosilovich, M. G., Schubert, S. D., Takacs, L., Kim, G.-K., Bloom, S., Chen, J., Collins, D., Conaty, A., da Silva, A., Gu, W., Joiner, J., Koster, K. D., Lucchesi, R.,Molod, A., Owens, T., Pawson, S., Pegion, P., Redder, C. R., Reichle, R., Robertson, F. R., Ruddick, A. G., Sienkiewicz, M., and Woollen, J.: MERRA: NASA's modern-era retrospective analysis for research and applications, J. Clim., 24, 3624-3648, doi:10.1175/JCLI-D-11-00015.1, 2011.

Roeckner, E., Brokopf, R., Esch, M., Giorgetta, M. Hagemann, S., and Kornblueh, L.: Sensitivity of simulated climate to horizontal and vertical resolution in the ECHAM5 atmosphere model, J. Climate, 19, 3771-3791, 2006.

Sinnhuber, B.-M., Stiller, G., Ruhnke, R., von Clarmann, T., Kellmann, S., and Aschmann, J.: Arctic winter 2010/2011 at the brink of an ozone hole, Geophys. Res. Lett., 38, L24814, doi:10.1029/2011GL049784, 2011.

SPARC CCMVal, Eyring, V., Shepherd, T. G., and Waugh, D. W. (Eds.): SPARC Report on the Evaluation of ChemistryClimate Models, SPARC Report No. 5, WCRP-132, WMO/TDNo. 1526, available at: http://www.atmosp.physics.utoronto.ca/ SPARC (last access: December 2012), 2010.

Thompson, D. W. J., Seidel, D. J., Randel, W. J., Zou, C.-Z., Butler, A. H., Mears, C., Osso, A., Long, C., and Lin, R.: The mystery of recent stratospheric temperature trends, Nature, 491, 692697, doi:10.1038/nature11579, 2012.

Wang, L. and Waugh, D. W.: Chemistry-climate model simulations of recent trends in lower stratospheric temperature and stratospheric residual circulation, J. Geophys. Res., 117, D09109, doi:10.1029/2011JD017130, 2012.

WMO: Scientific Assessment of Ozone Depletion: 2010, Global Ozone Research and Monitoring Project - Report No. 52, World Meteorological Organization, Geneva, Switzerland, 516 pp., 2011.

Young, P. J., Thompson, D. W. J., Rosenlof, K. H., Solomon, S., and Lamarque, J.-F.: The seasonal cycle and interannual variability in stratospheric temperatures and links to the Brewer-Dobson cir- 
culation: An analysis of MSU and SSU data, J. Clim., 24, 62436258, 2011.

Young, P. J., Rosenlof, K. H., Solomon, S., Sherwood, S. C., Fu, Q., and Lamarque, J.-F.: Changes in stratospheric temperatures and their implications for changes in the Brewer-Dobson circulation, 1979-2005, J. Clim., 25, 1759-1772, 2012.
Young, P. J., Butler, A. H., Calvo, N., Haimberger, L., Kushner, P. J., Marsh, D. R., Randel, W. J., and Rosenlof, K. H.: Agreement in late twentieth century southern hemisphere stratospheric temperature trends in observations and CCMVal2, CMIP3, and CMIP5 models, J. Geophys. Res., 118, 605-613, doi:10.1002/jgrd.50126, 2013. 